Educational Research for Social Change (ERSC)

Volume: 6 No. 2, September 2017

pp. 101-114

ersc.nmmu.ac.za

ISSN: 2221-4070

\title{
Phantasmagoria: Communicating an Illusion of Entrepreneurship in South African School Textbooks
}

Suriamurthee Moonsamy Maistry

University of KwaZulu-Natal

maistrys@ukzn.ac.za

Roshnee David

University of KwaZulu-Natal

roshneedavid@yahoo.com

\begin{abstract}
In this article, we examine discourses of entrepreneurship manifest in selected textbooks used in South African primary schools in the postapartheid era. While an attempt was made to purge school textbooks of discriminatory subject matter, the extent to which new powerful discourses have replaced apartheid ideology remains unknown. There is little dispute that school textbook content communicates subliminal messages about the world. Using critical discourse analysis, we reveal constituted and constitutive ideology at work in the textbooks under study. A dominant discourse that emerged was that individuals in society are responsible for their own economic sustainability despite prevailing and historic conditions of oppression and subjugation, and that entrepreneurship is a readily viable way to achieve economic emancipation because it naturally leads to wealth creation. It communicates as a subtle yet deliberate attempt by the state to displace its responsibility for the economic welfare of the individual citizen. The textbooks uncritically legitimate the values of the neoliberal market system. In this paper, we urge the development of a heightened sensitivity when teacher educators, teachers, and learners engage with such ideological persuasions.
\end{abstract}

Keywords: critical discourse analysis, entrepreneurship, textbooks, neoliberalism, ideology

Copyright: (c) 2017 Maistry \& David

This is an open access article distributed under the terms of the Creative Commons Attribution Non-Commercial License, which permits unrestricted non-commercial use, distribution, and reproduction in any medium, provided the original author and source are credited.

Please reference as:

Maistry, M. \& David, R. (2017). Knowledge as Enablement: Phantasmagoria: Communicating an Illusion of Entrepreneurship in South African School Textbooks Educational Research for Social Change, 5(2), 101-114. http://dx.doi.org/10.17159/2221-4070/2017/v6i2a7 


\section{Introduction}

Phantasmagoria is the outcome of a process that employs deceptive techniques, both through textual manipulation and semiotic selections, to create an illusion about a phenomenon. In this instance, the focus of this paper is the illusion of entrepreneurship as phantasm that is presented in school textbooks. There is little contention that school textbooks continue to be an important and indispensable resource for both teachers and learners in South African schools. Although the process of content cleansing continues to unfold, as evidenced by the aims of the 2016 Ministerial Committee's mandate to develop a textbook policy aimed at addressing diversity and ridding South African textbooks of prejudicial content, there is still a dearth of knowledge as to the ideological subtexts of textbooks in the economic sciences internationally (Ferguson, Collison, Power, \& Stevenson, 2009), and the new generation South African school economic sciences textbooks in particular.

Economic and management sciences (EMS) is a uniquely South African fabrication designed to serve a particular agenda, namely to enable learners to understand the wealth creation process and develop entrepreneurial dispositions (Department of Basic Education, 2011, pp. 8-11). EMS textbooks (the programmatic curriculum) were subsequently designed to meet these official curriculum objectives. Of significance for this paper is the ideological obfuscation (Zizek, 2011) that masks the curriculum's and the nation's relatively new romance with neoconservative-neoliberal economic discourses (Harvey, 2007), and how this is given effect in school textbooks. Fairclough $(2003,2009)$ reminded us that discourse is constitutive, having the power to shape constructions of reality. Through a process of systematic analysis, using critical discourse analysis (CDA) techniques, this paper attempts to illuminate how powerful ideologies are maintained and reinforced via the textbook - with a view to contemplating ways to disrupt this, and ways to engender social change.

Discourse and ideology have been a focus of repeated investigation in CDA (see Fairclough, 2009, 2011; Knain, 2001; MacLure, 2003; Mautner, 2008; Reisigl \& Wodak, 2009; van Dijk, 2009, 2011; Wodak \& Krzyzanowski, 2008). Ideology has its origins in the early 1800s in the work of Destutt de Tracy, but has generally been linked to Karl Marx (as cited in Machin \& Mayr, 2012). Ideology, according to Marx and Engels, denotes the body of intellectual thoughts used to support the economic domination and subjugation of particular classes (as cited in Machin \& Mayr, 2012). It refers to a systematic schema of ideas and discursive orientations about the functioning of society. Ideology operates first at an institutional level-that is, school or family-and then at the level of consciousness, thus making schools powerful ideological apparatuses given the presumed neutrality and naturalness of school education (Althusser, 2008). Ideology may also be viewed as a subtle yet powerful mechanism for the systematic cognitive distortion and manipulation of subjects' constructions of how society should be understood, thus serving a legitimising function for the maintenance of relations of power (Beaton, 2007). Note, though, that ideologies may also be used in resistance and struggle politics, as in antiracist, anti-xenophobic, or anti-sexist ideologies where sociopolitical circumstances may well engender liberating ideologies (van Dijk, 2011).

Current sociopolitical circumstances in South Africa may well manifest in representations of entrepreneurship in school textbooks that are likely to serve particular agendas, the revelation of which is not always obvious to the ordinary teacher (Maistry \& Pillay, 2014). Critical linguistics skills (using critical discourse analysis) are essential if individuals (teachers and learners) wish to unearth the subtext of school textbooks. The aim of this article therefore is to illuminate both constituted ideology and constitutive ideology at work in the selected texts. The former refers to "empirical manipulations and distortions at the level of content," and the latter to "the ideological form which provides the coordinates of the very space within which the content is located" (Zizek, 2011, p. 55). 
The potential of CDA research to trigger social change as it relates to curriculum reform and pedagogy is well documented (Rogers, 2011; Wodak, 2005; Wodak \& Krzyzanowski, 2008; Wodak \& Meyer, 2009). In its application to the study of ideology in school textbooks, CDA reveals how belief systems come to be, how they take hold, and how they acquire a kind of naturalness. Ideology has the power to "control and organise" beliefs to the extent that it shapes and controls attitudes toward social phenomena (van Dijk, 2006, p. 116). In this paper, we expose how neoliberal ideology is likely to shape attitudes and beliefs about entrepreneurship, endemic poverty, personal accountability, and state responsibility for individual and societal welfare, and how such ideology serves a powerful legitimating function. We argue that preservice and in-service teacher education programmes can be useful mechanisms to raise the level of consciousness amongst teachers about the workings of covert agendas that manifest in school curricula. The intention, then, would be to develop a counter discourse, an agentic counter hegemony and activism - a necessary social change because it relates to alleviating the plight of the poor and disenfranchised.

\section{A Brief Overview of Key Issues in the Extant Literature}

Concerns have been raised internationally regarding the role played by ideologies in business education, particularly those that uncritically support and promote exploitative capitalism and neoliberalism (Ferguson et al., 2009; McPhail, 2004; Zhang, 2012). School textbooks are likely to carry this ideological orientation, as is evidenced in accounting textbooks (McPhail, 2004). Business education legitimates the interests of corporate stakeholders (Collison, 2003). Capitalism and neoliberalism, with their practices of personal wealth accumulation, entrepreneurial choices, and unencumbered free trade, have an insidious effect on our ways of thought and our economic practices. This hegemonic discourse is now pervasive to the point of being taken as commonsense understanding of the way in which we should live and construe the world (Harvey, 2007). Writers of textbooks often propagate ideologies that serve to maintain the status quo as it relates to the order of the economic world (Cameron, Ireland, Lussier, New, \& Robbins, 2003). Paxton argued that the discourse of canonisation used as technique by economics textbook writers gives the impression that contentious statements stand as facts (Paxton, 2007).

With regard to entrepreneurship in particular, there appears to be a distinct and uncritical glamorisation of entrepreneurship in contemporary entrepreneurship literature, signalling it as the answer to the poverty crisis that, most especially, faces underdeveloped nations (Barbosa \& Ferreira, 2015; Jones \& Murtola, 2012). The trend is to emphasise heroism, success, hope, and rewards (Spicer, 2012; Weiskopf \& Steyaert, 2009). The lure created by careful, deliberate lexical constructions that utilise words such as endurance, passion, love, commitment, and perseverance (da Costa \& Saraiva, 2012) reinforces the appeal of entrepreneurship as an activity to aspire toward. Jones and Spicer (2009) and Spicer (2012) noted, however, that the discourse on entrepreneurship is silent on the negative ramifications (both material and psychological) that plague this livelihood. Also of concern is the preoccupation with individual self-advancement through entrepreneurship as opposed to a concern with societal welfare (Berglund \& Wigren, 2012).

\section{A Brief Methodological Note}

Although textbooks and policies present an air of impartiality that makes it difficult to identify ideological bias, CDA can unearth the hidden bias and subtext. Critical discourse analysis first emerged in discourse investigations in the 1980s in Europe, led by Norman Fairclough, Ruth Wodak, Theo van Leeuwen, Gerlinde Mautner, and Teun van Dijk. Theoretical influences that informed these critical researchers include Marx, Foucault, Moscovici, and Halliday (as cited in Wodak \& Meyer, 2009). A major concern for critical analysts is how texts can be representations of ideologies and can contribute to social relations of power and domination. 
CDA concerns itself with relations of power and inequality that are transmitted via language (Blommaert, 2005), and has the potential to reveal how certain ideological agendas are dispersed through choice discourses. It can be used to understand the power and control exercised by language (Wodak, 1996). Similarly, van Dijk (1998) noted that CDA helps to unravel discourse: the words we use to express something. Key analytical constructs used in this study included foregrounding, backgrounding, and topicalisation, embellishments, assumptions, insinuations, silences and omissions, nominalisation, modality, and register (Huckin, 1997, see Table 1). For a full corpus of data in each of these categories, see David (2012).

Table 1: Key Analytical Constructs (Adapted from Huckin, 1997)

\begin{tabular}{|c|c|}
\hline Feature & Explanation \\
\hline $\begin{array}{l}\text { 1. Foregrounding, backgrounding, and } \\
\text { topicalisation }\end{array}$ & Using keywords to emphasise certain concepts \\
\hline 2. Embellishments & $\begin{array}{l}\text { Using diagrams and sketches to get the reader's } \\
\text { attention }\end{array}$ \\
\hline $\begin{array}{l}\text { 3. "Taken-for-granted" words and } \\
\text { assumptions }\end{array}$ & Using certain words that take certain ideas for granted \\
\hline 4. Insinuations & $\begin{array}{l}\text { Selected words that have double meanings or that can } \\
\text { be misleading }\end{array}$ \\
\hline 5. Silences and omissions & $\begin{array}{l}\text { Leaving out or selecting out certain things; a silence on } \\
\text { pertinent issues }\end{array}$ \\
\hline 6. Nominalisation & Changing a verb into a noun \\
\hline 7. Modality & $\begin{array}{l}\text { The tone of the text conveyed by the use of modal verbs, } \\
\text { adverbs, and adjectives }\end{array}$ \\
\hline 8. Register & Single words can suggest if words spoken ring true \\
\hline
\end{tabular}

A sample was drawn of three economic and management sciences textbooks ( $A, B$, and $C$ ) approved by the Department of Basic Education and in use in Grade 7. Because entrepreneurship was a key topic in the curriculum, each textbook had dedicated chapters for this aspect of the curriculum. These constituted the sampled chapters. All three textbooks were published in South Africa. Note that although textbooks are in the public domain, a decision to keep their identities anonymous was taken in an attempt to avoid ethical or litigious issues that could arise. An analysis of the discourses of entrepreneurship is presented in the section follows.

\section{Pervasive Discourse of Guilt and Personal Accountability, and Reckless Romanticising of Entrepreneurial Success}

In the analysis and discussion below, we present an exposé of how the lexical choices appropriated by the sampled texts perform two ideological functions - they constantly reemphasise, firstly, that human subjects are ultimately responsible for their own personal and economic welfare irrespective of their historic and prevailing personal conditions of existence and, secondly, that a sure way to ensure one's ability to sustain oneself is by becoming an entrepreneur. Entrepreneurship is presented as a viable, lucrative, and easily achievable vehicle for any individual, should she or he wish to exercise this freedom of choice. 


\section{Reckless romanticising.}

In Textbook C, keywords are foregrounded to emphasise a positive conception of entrepreneurship. Words like initiative, creativity, and viable business opportunity instil the idea that entrepreneurship is the answer to an individual's economic predicament. In Textbook B (p. 60), a case study begins with the phrase "The winner of the 2003 Technology Women in Business award." This foregrounds very emphatically the idea of pervasive success.

The recurring subtext in each data source is the taken-for-granted assumption that entrepreneurship can only be successful. This is presented in a forthright manner and with a fair degree of authority. In Textbook B, there is an overt example of this tone of certainty and authority in the chapter title, "What it takes to be a successful entrepreneur" (p. 57), which emphatically foregrounds the notion of success.

Using to be, referencing a present state, rather than to become, referencing a future state, gives certainty and authority to the register. In addition, the title might potentially have been phrased as a question (beginning with "What ...") but avoids doing so. The phrasing reinforces both presumed certainty of entrepreneurial success and the authority of the knowledge that is forthcoming in the chapter. The idea of entrepreneurial success is reified in multiple instances. This assertion is likely to falsely lead the young reader to believe in this automatic success. Further instances of this persuasive presentation are reflected in the case studies that project authoritative assertions based on presuppositions and statements avowed as facts. In Textbook B, Case Study 2, there is a typical example of a presupposition authoritatively asserting the notion of entrepreneurial success as natural, irrespective of the size of the business: "Tholakele believes other rural women should start their own businesses, no matter how small. They should combine their skills as the four women did" (p. 60). The word believes indicates conviction and certainty. The notion of any business irrespective of size, projects the myth at this point that in any economy business size could be an unimportant factor. On the contrary, size does matter because small-scale businesses struggle to remain sustainable in the presence of fierce competition and unfair advantage enjoyed by large established businesses.

The text then implores women to work together, projecting the idea that working together in business is the way to create wealth for rural women. There is, however, no factual evidence that the outcome of entrepreneurial pursuits always results in positive outcomes. The tone of this section on entrepreneurship is set by the the modal verb should to convey a degree of certainty and authority that Tholakele supposedly has on this subject, although her knowledge is just based on her personal, somewhat limited, experience. A further assumption projected by the text is that all other rural women are the same and have the same capabilities. This perspective on entrepreneurial success downplays other key factors that are likely to play a significant role in entrepreneurial success.

In the same text, the case is presented of a young schoolboy running a successful business at school. The first ideological move in this instance is to naturalise the "normality" of the school as a legitimate site for business activities by primary-school children. Here the text uncritically presents schools as legitimate sites for profit making and material wealth accumulation by learners. This value orientation constitutes a significant digression from the traditional purpose of school education. There is silence on the social responsibility aspects.

In Textbook C, a case study is used to make emphatic assertions: "With her drive, creativity, and natural teaching ability, Irma inspires, guides, and develops potential talent. Irma has successfully combined creativity with sound business practices" (p. 122). These are strong categorical "facts," devoid of words suggesting modality or tentativeness about entrepreneurial success, and projective of somewhat 
unrealistic expectations in a reader who may not be aware of immanent risks in the business environment.

In Textbook C, (p. 120) a photograph is presented of a woman standing outside her corrugated-ironroofed house in a South African township. The textbook describes townships as mass, low-cost housing schemes, which in a South African context are characterised by a mix of semiformal housing and informal settlements inhabited mainly by people of colour from the poor and the working class. The potential reader is led to believe that in the context of extreme deprivation, entrepreneurial success could happen despite the level of deprivation. The subtext is that one can reinvent oneself and become a wealthy entrepreneur despite one's prevailing context. This romanticising of entrepreneurial success is further reinforced by suggesting that people in poor communities can harness the potential of their poor and disadvantaged contexts by marketing and packaging it as a an exotic cultural experience that tourists could enjoy. This has a somewhat patronising undertone because it trivialises the hardship and repressive conditions that poor communities endure in these townships. Of significance, is the idea that a marketable package can be constructed for sale of a new exotic product, namely, human suffering. In other words, how the poor live, can easily be commodified as "township travel" and sold in the tourism market. This is evident in the following excerpts:

Township travel is good news for the people who own and manage guesthouses and B\&Bs. And many of them are ordinary women who have embraced tourism with typical South African enthusiasm.

[It] not only offers a rewarding cultural exchange, but the promise of a better life. (Textbook C, p. 120)

The phrase, typical South African enthusiasm, presents as a somewhat naïve generalisation about the entire South African population. In a country plagued by high unemployment and poverty, it is presumptuous to make such an assertion. Constant service delivery protests and other forms of civil disobedience and anti-state demonstrations suggest that the kind of national enthusiasm suggested by the text is somewhat improbable. This kind of euphoric sentiment is likely to work toward quelling the urge for civil uprising because it suggests that human beings, despite their deplorable conditions of existence, can exercise free will in order to overcome these conditions. As such, it plays down restrictive and oppressive structural issues that have prevented the poor from rising above their condition to attain a better life.

The exclusive them in the extract extends this patronising tone and it is further maintained in the phrase ordinary women. A level of unwitting othering is evident, but disguised as a positive manifestation. The plight of the township-dwelling woman is also trivialised, reducing these female citizens to ordinariness. The use of the word many, without any specific mention of exactly what number of women are involved, creates the impression that this is a widespread phenomenon, but without any firm evidence to support this. The text presents this statement emphatically in the present tense: that this is good news.

\section{About guilt and personal accountability.}

The extracts below from a section entitled, "Reasons Why People Become Entrepreneurs" is an example of how the text uses persuasive scare tactics to suggest to the potential primary-school reader that entrepreneurship is the only likely pathway to success in the given social context. 
'We had 273 applicants for the last job we advertised in the newspaper.'

'I would like to become an entrepreneur because I'm very frustrated. My job's so boring and the pay is low.'

'I work so hard but the company gets all the money.'

'I did matric three years ago. I've been looking for work since then. I've had no luck finding a job.'

'I didn't have a chance to go to school for long. It's hard to get a job without qualifications.' (Textbook C, p. 61)

Each alarmist quote is used to represent the dreaded unemployment that might be the consequence if people choose not to be entrepreneurs. All the quotations in this extract give consent to the concept of entrepreneurship to legitimate this hegemony. Several ideological undertones are at play here. Firstly, the oversubscription of job applications for a single vacancy is likely to induce a sense of despair and desperation amongst the young readers of this text. A feeling of hopelessness as a result of a high competition for jobs is presented. There is silence on the type of job, the remuneration, the geographical location, the conditions of employment, and so forth, which may have stimulated such a high number of applicants. Secondly, there is an overt assertion that entrepreneurship is likely to be more stimulating and exciting as opposed to working for an employer who reaps the financial rewards. Stress, fatigue, anxiety, and depression are common afflictions associated with entrepreneurship, yet no hint is given of this dimension of an entrepreneurial livelihood. The comment about the futility of the effort it requires in having a job may unwittingly suggest to the potential reader that entrepreneurship may not be as strenuous and demanding as holding down a job. A further subliminal message is that workers are relatively powerless in negotiating a fair share of the income that businesses generate. This message could work to signal the likely benefits of power that comes with being an entrepreneur, in a context where workers' rights and power to negotiate are weak, thus making entrepreneurship seem more powerful and appealing while being an employee seems less attractive. The last two quotes are particularly troubling because they declare limited education as impediments to securing a good job. Yet the text appears to uncritically present this context as an opportunity, by presenting it as a strong rationale for starting one's own business. There is a myth projected that one's "natural" business acumen will automatically take effect when human subjects face adversity and that existing everyday knowledge is a sufficient qualification for one to take on the risks (financial and other) that are involved in starting up one's own business.

A further distinct impression created here is that the disadvantaged must accept as an inevitable fact that unemployment is something one has to live with, unless (it is implied) one becomes an entrepreneur. This is conveyed by the following forthright comment in the text: "Long term unemployment is a problem for many people in South Africa" (Textbook C, p. 61). This presents the notion that unemployment is something permanent and long term. If a person is unemployed it is not something that can be rectified but will instead probably become an enduring feature of one's economic life. There is no attempt to offer reasons for structural unemployment. This suggests to the young readers that they must accept that this is how things are. The onus appears to be on the individual to find a way out of this economic dilemma because there is no attempt in the text to explain the role of the state or of existing business in providing opportunities for economic livelihood. Poverty, unemployment, failure, and working for others are seen as undesirable. On the other hand, entrepreneurship is portrayed as positive, desirable, empowering, and potentially profit making. 
Another persuasive technique employed entails the shift from the third person to the second person and then to the first person in the various utterances. In Textbook $C$, the writer began the paragraph that describes what an entrepreneur is by couching the definition in the third person, using the pronouns their and they in referring to the characteristics and skills of an entrepreneur: "Entrepreneurs use their initiative and creativity to turn this idea into reality. They find a way to finance and start their businesses and to make it work" (p. 119). Initiative and creativity are two characteristics that are mentioned. The writer then switches to the second person you to tersely state that entrepreneurs take calculated risks: "You will often hear that entrepreneurs take calculated risks" (p. 119). Two social identities are constructed by the text here with the use of they and you. The use of they constructs a select group as powerful and successful, while the use of you suggests that if an individual is not an entrepreneur then she or he is likely to fall into the category of being uncreative and without initiative. This wilful and careless inclusion and exclusion reinforces the likelihood of negative self-constructions by young readers who may self-exclude. The language suggests that entrepreneurs belong in society and are "good" for society. Negative aspects are omitted or mentioned superficially. There are powerful groups that the text wills readers to identify with. This effortless switching reinforces the notion that the young reader has the potential to readily access the world of entrepreneurship, and that it would be fundamentally as a result of her or his own dispositions that they might exclude themselves from a life of economic success. At the end of the chapter (Textbook C, p. 123), after presenting success stories of specific entrepreneurs, the text persuasively embraces the young reader in an encompassing statement that "we all have some entrepreneurial potential but we may not be aware of it." For the first time in this chapter the text changes to the inclusive we to include the reader, expressing a collective consensus that everyone has latent potential to become entrepreneurs. Subjects should therefore aspire to develop this latent potential for inclusion in the power group. The text thus effectively applies a subtle yet persuasive device in the shift of pronouns from they, to you, and finally to we. There is, however, no explanation of how subjects may move from an initial state of unawareness to a condition of effective operation as an entrepreneur.

There is also a notable silence on the reality of life in South Africa in terms of the unevenness of the economic and business terrain, and of differing capabilities, acumen, access to finance and opportunities that pupils in urban and rural South Africa are exposed to. There is also a notable omission of the difficulty that new entrepreneurs experience in the process of accessing finance.

The omission of risk as a crucial aspect of entrepreneurship is a cause for concern. The textbooks select in some knowledge and select out other knowledge. Risks associated with entrepreneurship are backgrounded, and in some case studies totally omitted. There appears to be an uncritical advocacy for perseverance in the face of business adversity as opposed to making sound judgments for continuance on the basis of existing economic and business information, as conveyed in the following loose comment: "- one of the hardest things for an entrepreneur is to never give up" (Textbook B, p. 58). In another instance, the text states forthrightly that entrepreneurs experience failure before they reach success, as if this is a normal pattern. There is no elaboration on key issues that may include the cause of failure or the length of time an entrepreneur should persevere. Failure is recklessly glorified here while the traumatic consequences of failure are totally omitted. The extent of devastation and loss of self-esteem that may come with entrepreneurial failure is completely ignored.

\section{Discussion}

One can discern a subtle and somewhat sinister political agenda playing itself out in the programmatic curriculum followed by the school textbook. The taken-for-granted assumption that entrepreneurial success is a certainty and the right route to pursue for accumulation of wealth distorts the reality of entrepreneurship's potential to deliver on either personal or collective emancipation. Entrepreneurship is romanticised, despite current research that indicates that entrepreneurial start- 
up is severely hampered by poverty, level of education, and access to capital (Kelly, Singer, \& Herrington, 2016). Zizek (2011, p. 55) referred to this as "constituted ideology" - an overt manipulation and distortion of content, a discursive practice we need to be deeply sceptical of. Entrepreneurship is seen as positive and desirable and empowering; hope for a prosperous future depends on individuals developing their own livelihoods through entrepreneurship, with emphasis on the need for selfmanagement. At work here is a powerful manifestation of interpellation: a process in which neoliberal ideology addresses the individual. This aggressive move via the curriculum is an example of what de Vos described as contemporary psychologization (de Vos, 2012), which is a systematic harnessing of multiple technologies to influence our thoughts and experiences in terms of a capitalist rationality. Zizek cautioned about the sublime object of ideology in conditions of psychologisation (Zizek, 2008)a scenario that is clearly being played out in the texts under study.

Entrepreneurship is presented as leading to success in every instance, irrespective of the size of the business, the age of the entrepreneur, or the situation of the business venture; any business can succeed irrespective of size. In reality, however, small-scale businesses struggle to remain sustainable in the presence of large businesses. Profit making and competition are presented as acceptable and desirable values, which should be taught to young learners-a subtle yet powerful ideological move that reflects the constitutive ideology at play in these texts. Zizek warned that capitalism is akin to a religion; it relies on faith in the institutions of money, profit, and wealth accumulation. What can be discerned here is the "cynical functioning of ideology which deliberately 'obscures the religious core of capitalist beliefs"' (Zizek, 2011, p. 130).

Of concern is that the school (as a representation of where education occurs) is presented as a legitimate, unquestioned site for profit making, as if this is a commonsense notion. Torres urged that there is a need to examine how the new neoliberal commonsense has come to be and how it has percolated into education (Torres, 2011). The curriculum, in this instance, legitimises the practice of wealth accumulation. Although it is commonly recognised that economics and education are intricately connected (Maistry, 2012), opinions differ as to the optimal extent, nature, and form for this connection. It raises fundamental questions about how society constructs the purpose of education and what has become of the traditional purpose of education, which is to develop ethical citizens with a strong social consciousness (Nussbaum, 2010). The process of personal wealth creation is also legitimated by using words and phrases that give a positive connotation to personal wealth creation, which is a neoliberal inclination. Working for an employer or holding a job is constructed as undesirable and less challenging, and not as gratifying as having one's own business. The problem is that this is presented in a rather uncritical manner.

The textbooks under study clearly subscribe to a neoliberal value system that attaches value to efficiency, personal wealth accumulation, and self-advancement (Harvey, 2007; Maistry, 2012; Zhang, 2012). The economically fittest in society thrive in the pursuit of wealth. To the untrained eye, this accumulation of personal wealth appears persuasive and appealing (Maistry, 2012). While we recognise and acknowledge the power of individual agency that may reside in learners in the way they engage with textbook theory, it will be remiss not to illuminate the potential for interpretation and internalisation by learners whose agency may not be as profound. To such learners, it might well entail a process of systematic psychological blackmail in which there are constructions of inability to "succeed" that instil in them, feelings of inadequacy, deficiency, and lacking if they do not take up the proposition presented by the text. Of particular concern is the notable silence on the reality of life in South Africa. Issues of the unevenness of economic terrain and of differing capabilities, acumen, access to finance and opportunities are lived realities in a South African context. Zizek reminded us that we need to be alert to the way ideology blurs the "background noise" through a reductive simplification of real world problems (Zizek, 2011, p. 5). He warned that "such an erasure of the background noise is the very core of utopian dreaming" (Zizek, 2011, p. 5). The threat of unemployment is also used in an 
attempt to convince the young reader that, in South Africa, entrepreneurship is the answer to unemployment. Potential readers are boldly informed that unemployment is an inevitable reality in South Africa unless one can become an entrepreneur. Living in poverty or being unemployed is dealt with in a rather reductive fashion - the human subject is typified as shameful and deficient in the traits needed to elevate oneself from one's economic predicament. Claims about entrepreneurship in the texts examined chiefly emphasised the positive benefits of successful entrepreneurship, with very limited reference to the risks and challenges associated with entrepreneurship. Little attention was paid to the capabilities, human abilities, or entrepreneurial challenges that are involved in entrepreneurial ventures, or to the devastation and trauma that are associated with their failure. In fact, there was complete silence on issues of trauma related to failure. Here again, it is possible to discern constitutive ideology at work. The threat to personal well-being and employment sustainability appears to be inscribed into the institutional frame of South African economic and political society. We see a construction of myth - of an alternate reality that disguises the real cause of people's current condition. The poor are constructed as naturally caught up in the vicissitudes of historic apartheidcreated poverty, from which only they have the power to extricate themselves if they really put their minds to it by summoning up their inherent entrepreneurial capabilities and by aspiring to particular entrepreneurial virtues. A patent illusion is presented of (economic) freedom of choice that primaryschool children, irrespective of socioeconomic context, have and can exercise without constraint. Zizek (2011, p. 359) cautioned, though, that "freedom of choice operates only when a complex network of legal, educational, ethical, economic and other conditions form an invisible thick background to the exercises of our freedom." People are forced to choose without having at their disposal the kind of knowledge that will allow them to make proper choices. Ideology works in a way in that serves to obliterate the ethico-political background and fundamental cause of poverty and unemployment in South Africa; subjects simply need to need to accept the situation the way it is and find their own salvation.

Textbooks thus have latent potential as instruments of propaganda, uncritically promoting the ideals of capitalism and neoliberalism, and inculcating in students a particular worldview that draws on the values and assumptions of capitalism (Ferguson, Collison, Power, \& Stevenson, 2005; Ferguson et al., 2009; Kelly \& Pratt, 1994; McPhail, 1999; Zhang, 2012). Students are seldom offered an alternate viewpoint, which would be other ways in which organised society can function, not necessarily just based on an Anglo-Saxon capitalistic model.

So what then are the implications of this analysis for classroom teaching? In keeping with the epistemological and ontological thrust of this article, we resist the temptation to offer concrete recommendations for classroom practice. We do however reiterate the argument that this paper presents, namely, that ideology has the power to naturalise historic processes that have given shape to current conditions of socioeconomic existence for many South Africans. As such, active and alert subjects (teacher educators, teachers, and learners) might need to develop a heightened sensitivity to the way particular worldviews are constructed in texts. A key challenge prevails, namely that "the truth about capitalism must entail a historic break with it, a break with capitalism" (Parker, 2013, p. 25); there has to be a disruption to the psyche of the aforementioned subjects that is likely to create much cognitive dissonance. It necessarily demands robust introspection in regard to our passive, uncritical assimilation of and complicity in capitalist ideology. It is only then that we can contemplate the idea of emancipation. The study thus raises pertinent research questions as to the ideological inclinations of teachers themselves, and the pedagogical strategies that might apply in invoking rupture and dissonance. 


\section{Theorising the selection and construction of discourse in school textbooks: The state as monopoly agent.}

Textbook industry is essentially a profit driven industry that has to meet the very specific needs of its target market. In the South African context, the state is the most powerful player in this market because it provides the regulatory frame for textbook production as well as performing a quality assurance and content vetting role. That macro policy such as the National Development Plan (National Planning Commission, 2011) permeates into school curriculum policy is a moot point. As such, state ideology is more than likely to manifest in the curriculum content selections for school subjects. In essence, the state exercises significant power over the content of school textbooks. Once screened for suitability, sanctified textbooks appear on the state's approved textbook lists, which are distributed to schools and state procurement agents. Rejected textbooks that do pass the state's selection protocol might, likely, not feature on the profit potential recommended lists, and as such, are stripped of their economic value. It is thus reasonable to assume that publishers would want to create artefacts designed to gain approval by state regulatory agents. It is also reasonable to assume that content that might critique the state's declared agenda in official curriculum documents might not find favour with state vetting authorities. It follows then that publishers, in the selection of knowledge to flesh out content topics stipulated in official curriculum documents, might inadvertently be purveyors of state discourses via the textbooks they create. Any deviation from state prescriptions might be at the cost of market share (and profit) in an already competitive textbook publishing industry. It can be argued then that the current structural arrangement centres the state as ideology prescriber and mediator: a hegemony derived from its persuasive role as monopoly agent in the textbook arena. Thus, the absence of nonpartisan, independent, scholarly informed, nonprofit oversight regulatory bodies for the textbook industry renders textbook content, in the South African context, hostage to the agenda of the state. Textbook publishers (corporates with a profit motive) have wised up to the rules of the game, indulge the compliance imperative, essentially rendering them complicit in pursuing their enterprise.

\section{Conclusion}

What then might the implications of this study be for social change as it relates to education? In a seminal piece entitled Pedagogy of the Oppressed, Paulo Freire (1998) argued that traditional pedagogy was inadequate in providing learning contexts that illuminate inequality or could offer mechanisms for individual and societal emancipation. There is thus a need for a different kind of teaching, a teaching to transgress, a critical pedagogy, as we aspire toward social change (Giroux, 2004; hooks, 1994; McLaren, 2003). Just over a decade ago, Henri Giroux cautioned that "the forces of neoliberalism are on the march, dismantling the historically guaranteed social provisions provided by the welfare state, defining profit making and market freedoms as the essence of democracy, while diminishing civil liberties" (Giroux, 2004, p. 31). He argued that this agenda benefits a few but has the seeds of its own destruction. The current Fees Must Fall! protest action that is being witnessed across South Africa can be seen as a direct revolution against entrenched capitalism and neoliberalism. A disenfranchised yet powerful sector of the South African community (poor students) has begun to threaten the current higher education system. While critical pedagogy certainly does not condone violence and wanton destruction of property, it does encourage the development of pedagogical spaces to engage learners in debates about responsible social action. A critical teacher education curriculum in which various discourses (including textbook discourses) are analysed critically is thus crucial in nurturing a new breed of critical, responsible learner. 


\section{References}

Althusser, L. (2008). On ideology. London, UK: Verso.

Barbosa, I., \& Ferreira, E. I. (2015). The "machine of entrepreneurship": The crisis in Portugal and a critical discourse analysis through the Theatre of the Oppressed. Procedia-Social and Behavioural Sciences, 197, 1250-1256.

Beaton, M. (2007). Interpreted ideologies in institutional discourse: The case of the European Parliament. The Trans/ator, 13(2), 271-296.

Berglund, K., \& Wigren, C. (2012). Soci(et)al entrepreneurship: The shaping of a different story on entrepreneurship. Tamara-Journal for Critical Organizational Inquiry, 10(1), 9-22.

Blommaert, J. (2005). Discourse: A critical introduction. New York, USA: Cambridge University Press.

Cameron, K. S., Ireland, R. D., Lussier, R. N., New, J. R., \& Robbins, S. P. (2003). Management textbooks as propoganda. Journal of Management Education, 27(6), 711.

Collison, D. J. (2003). Corporate propoganda: Its implications for accounting and accountability. Accounting, Auditing and Accountability Journal, 16, 853-886.

David, R. (2012). An exploration of ideology in economic and management sciences textbooks: A critical discourse analysis (Unpublished master's thesis). University of KwaZulu-Natal, South Africa.

Da Costa, A., \& Saraiva, L. A. S. (2012). Hegemonic discourses on entrepreneurship as an ideological mechanism for the reproduction of capital. Organization, 19(5), 587-614.

De Vos, J. (2012). Psychologisation in times of globalisation. London, UK: Routledge.

Department of Basic Education (DBE). (2011). National curriculum statement (NCS): Curriculum and assesment policy statement (Grades 7-9), economic and management sciences. Pretoria, South Africa: DBE.

Harvey, D. (2007). A brief history of neoliberalism. Oxford, UK: Oxford University Press.

Fairclough, N. (2003). Analysing discourse: Textual analysis for social research. London, UK: Routledge.

Fairclough, N. (2009). A dialectical-relational approach to critical discourse analysis. In R. Wodak \& M. Meyer (Eds.), Methods of critical discourse analysis (pp. 162-186). New York, USA: SAGE.

Fairclough, N. (2011). Semiotic aspects of social transformation and learning. In R. Rogers (Ed.), An introducrion to criticl discourse analysis in education (2nd ed., pp. 119-127).

Ferguson, J., Collison, D., Power, D., \& Stevenson, L. (2005). Accounting textbooks: Exploring the production of a cultural and political artifact. Accounting education, 15(3), 243-260.

Ferguson, J., Collison, D., Power, D., \& Stevenson, L. (2009). Constructing meaning in the service of power: An analysis of typical modes of ideology in accounting textbooks. Critical Perspectives on Accounting, 20, 896-909.

Freire, P. (1998). Pedagogy of freedom: Ethics, democracy and civic courage. New York, USA: Rowman \& Littlefield.

Giroux, H. A. (2004). Critical pedagogy and the postmodern/modern divide: Towards a pedagogy of democratization. Teacher Education Quarterly, 31(1), 31-47.

Harvey, D. (2007). A brief history of neoliberalism. Oxford, UK: Oxford University Press.

hooks, b. (1994). Teaching to transgress: Education as the practice of freedom. New York, USA: Routledge.

Huckin, T. (1997). Critical discourse analysis. In T. Miller (Ed.), Functional approaches to written texts: Classroom applications (pp. 78-93). New York, USA: US Information Agency. 
Jones, C., \& Murtola, A. (2012). Entrepreneurship and expropriation. Organization, 19(5), 635-655.

Jones, C., \& Spicer, A. (2009). Unmasking the entrepreneur. Cheltenham, UK: Edward Elgar.

Kelly, M., \& Pratt, M. (1994). Management accounting texts in New Zealand: The need for a paradigm shift. Accounting Education, 3, 313-329.

Kelly, D., Singer, S., \& Herrington, D. (2016). Global Entrepreneurship Monitor. Retrieved from http://gemconsortium.org/report/49480

Knain, E. (2001). Ideologies in school science textbooks. International Journal of Science Education, 23(3), 312-329.

Machin, D., \& Mayr, A. (2012). How to do critical discourse analysis: A multimodal introduction. London, UK: SAGE.

MacLure, M. (2003). Discourse in educational and social research. Buckingham, UK: Open University Press.

Maistry, S. M. (2012). Foregrounding a social justice agenda in economic education: Critical reflections of a teacher education pedagogue. Journal for New Generation Sciences, 10(2), 30-45.

Maistry, S. M., \& Pillay, P. (2014). Gender representation in contemporary Grade 12 business studies textbooks. Perspectives in Education, 32(4), 74-92.

Mautner, G. (2008). Analyzing newspapers, magazines and other print media. In R. Wodak \& M. Krzyzanowski (Eds.), Qualititavive discourse analysis in the social sciences (pp. 30-54). New York, USA: Palgrave Macmillan.

McLaren, P. (2003). Critical pedagogy and class struggle in the age of neoliberal globalization: Notes from history's underside. Democracy and Nature, 9(1), 91-105.

McPhail, K. (1999). The threat of ethical accountants: An application of Foucault's concept of ethics to accounting education and some thoughts on ethically educating for the other. Critical Perspectives on Accounting, 10, 833-866.

McPhail, K. (2004). An emotional response to the state of accounting education: Developing accounting students' emotional intelligence. Critical Perspectives on Accounting, 15, 629-648.

National Planning Commission (NPC). (2011). National development plan: Vision for 2030. Pretoria, South Africa: NPC.

Nussbaum, M. C. (2010). Not for profit: Why democracy needs the social sciences. New Jersey, USA: Princeton University Press.

Parker, I. (2013). Zizek's sublime objects now. In J. Khader \& M. A. Rothenberg (Eds.), Zizek now: Current perspectives in Zizek studies. Cambridge, UK: Polity Press.

Paxton, M. (2007). Tensions between textbook pedagogy and the literacy practices of disciplinary community: A study of writing in first year economics. Journal of English for Academic Purposes, 6(2), 109-125.

Reisigl, M., \& Wodak, R. (2009). The discourse-historical approach (DHA). In R. Wodak \& M. Meyer (Eds.), Methods of critical discourse analysis (pp. 87-121). New York, USA: SAGE.

Rogers, R. (Ed.) (2011). An introduction to critical discourse analysis in education. London, UK: Routledge.

Spicer, A. (2012). Critical theories of entrepreneurship. In K. Mole \& M. Ram (Eds.), Perspectives in entrepreneurship: A critical approach (pp. 149-160). Hampshire, UK: Palgrave Macmillan.

Torres, C. (2011). Public universities and neoliberal common sense: Seven iconoclastic theses. International Studies in Sociology of Education, 21(3), 177-197. 
Van Dijk, T. (1998). Critical discourse analysis. In D. Tannan, D. Schiffren, \& H. Hamilton (Eds.), Handbook of discourse analysis (pp. 352-371). London, UK: Blackwell.

Van Dijk, T. (2006). Ideology and discourse analysis. Journal of Political Ideologies, 11(2), 115-140.

Van Dijk, T. A. (2009). Critical discourse studies: A sociocognitive approach. In R. Wodak \& M. Meyer (Eds.), Methods of critical discourse analysis (pp. 62-86). New York, USA: SAGE.

Van Dijk, T. A. (2011). Discourse and ideology. In T. A. van Dijk (Ed.), Discourse studies: A multidisciplinary introduction (pp. 379-407). London, UK: SAGE.

Weiskopf, R., \& Steyaert, C. (2009). Metamorphoses in entrepreneurship studies: Towards an affirmative politics of entrepreneuring. In D. Hjorth \& C. Steyaert (Eds.), The politics and aesthetics of entrepreneurship. Northhampton, UK: Elgar.

Wodak , R. (1996). Disorders of discourse. London, UK: Longman.

Wodak, R. (2005). Understanding and explaining social change: Deja vu experiences. International Journal of Applied Linguistics, 15(2), 240-243.

Wodak, R., \& Krzyzanowski, M. (Eds.). (2008). Qualitative discourse analysis in the social sciences. New York, USA: Palgrave Macmillan.

Wodak, R., \& Meyer, M. (2009). Critical discourse analysis: History, agenda, theory and methodology. In R. Wodak \& M. Meyer (Eds.), Methods of critical discourse analysis (pp. 1-34). London, UK: SAGE.

Zhang, W. (2012). Fair value accounting as an instrument of neoliberalism in China (Unpublished doctoral dissertation). University of Wollongong, Australia.

Zizek, S. (2008). The sublime object of ideology. New York, USA: Verso.

Zizek, S. (2011). Living in the end times. London, UK: Verso. 